Egypt J. Aquat. BioL\& Fish. Vol. 10,No.l:125 -138 (2006)ISSN 1110 - 6131

\title{
LIGHT AND SCANNING ELECTRON MICROSCOPE OBSERVATIONS OF HYSTEROTHYLACIUM WINTER TORRES AND SOTO, 2004 (NEMATODA :ANISAKIDAE) FROM BOOPS BOOPS MARINE FISH IN EGYPT
}

\author{
Dayhoum A.H. Al-Bassel \\ Zoology Depatement, Faculty of Science - Fayoum University, Egypt
}

Keywords: Light, Scanning, Hysterothylaciwn winteri, Boops boops

\begin{abstract}
T The nematode Hysterothylaciwn winteri Torres and Soto, 2004 was 1 studied in detail using bright field and scanning electron microscopes. jt was recorded for the first time from the intestine of the marine fish ops boops collected from Alexandria fish market in Egypt. The morphometric data presented here are in agreement with those described by Torres and Soto (2004) for the same species. The most characteristic features revealed in this study are the papillae and amphids of the ventral lips, the ventral groove and associated bands, cuticular spine-like structures on the conical tip of the tail, one pair of postanal papillae, 2 ilae, 6 longitudinal ridges and one pair of phasmid in the lateral part of die tail. The present findings were discussed in comparison with the previously described features of//, winteri.
\end{abstract}

